\title{
PENGARUH PENERAPAN MODEL PEMBELAJARAN KOOPERATIF TIPE STUDENT TEAM ACHIEVEMENT DIVISION (STAD) BERBANTUAN LEMBAR KERJA SISWA (LKS) TERHADAP HASIL BELAJAR KIMIA
}

\author{
Asman Ardiyansyah $^{1 *}$, Eka Junaidi ${ }^{2}$, Saprizal Hadisaputra ${ }^{3}$ \\ 1,2,3 Program Studi Pendidikan Kimia FKIP Universitas Mataram \\ *Coressponding Author, Email: laluardiangunaqan@gmail.com
}

Received: 10 Oktober 2019

Accepted: 30 November 2019

Publish: 30 November 2019

doi: 10.29303/cep.v2i2.1396

\begin{abstract}
ABSTRAK
Penelitian ini bertujuan untuk mengetahui pengaruh penerapan model pembelajaran kooperatif tipe Student Team Achievement Division (STAD) berbantuan lembar kerja siswa (LKS) terhadap hasil belajar kimia pada materi hidrokarbon siswa kelas XI IPA SMAN 7 Mataram. Jenis penelitian ini merupakan quasi eksperimen dalam bentuk non-equivalent control group design. Populasi dalam penelitian ini meliputi semua siswa kelas XI IPA SMAN 7 Mataram. Metode yang digunakan untuk pengambilan sampel yaitu dengan metode purposive sampling. Sampel dalam penelitian ini adalah yaitu kelas XI IPA 3 sebagai kelas eksperimen dan kelas XI IPA 1 sebagai kelas kontrol. Pada kelas kontrol diberi perlakuan dengan menggunakan model pembelajaran kooperatif tipe Student Team Achievement Division (STAD) berbantuan lembar kerja siswa (LKS) sedangkan pada kelas kontrol menggunakan model pembelajaran konvensional. Uji hipotesis pada penelitian ini menggunakan ujit.Hasil uji statistik pada taraf signifikan 5\% menunjukkan thitung $(3,76)>$ ttabel $(1,67)$. Nilai rata-rata kelas eksperimen sebesar 70,83 dengan ketuntasan klasikal sebesar 53,12\% lebih tinggi dibandingkan nilai rata-rata kelas kontrol sebesar 68,01 dengan ketuntasan klasikal 38,70\%. Berdasarkan hasil tersebut maka dapat disimpulkan bahwa penerapan model pembelajaran kooperatif tipe Student Team Achievement Division (STAD) berbantuan lembar kerja siswa (LKS) memberikan pengaruh yang lebih baik terhadap hasil belajar kimia pada materi senyawa hidrokarbon siswa kelas XI IPA SMAN 7 Mataram.
\end{abstract}

Kata kunci : model pembelajaran kooperatif tipe Student Team Achievement Division (STAD), lembar kerja siswa (LKS) dan hasil belajar

\section{THE EFFECT OF COOPERATIVE LEARNING MODEL STUDENT TEAM ACHIEVEMENT DIVISION (STAD) ASSISTED BY STUDENT WORKSHEET (LKS) TOWARDS LEARNING OUTCOMES}

\begin{abstract}
This research aims to investigate the effect cooperative leraning model Student Team Achievement Division (STAD) assisted by student worksheet (LKS) towards learning outcomes for chemistry subject matter of hidrocarbon students at class XI IPA SMAN 7 Mataram. Quasi experimental in the form of non-equvalent control group design is the type of this study. The population of this research was all students of XI IPA SMAN 7 Mataram. Purposive sampling method was chosen to be the sampling method of this study. The sampleof this study were XI IPA 3 as the experiment class and XI IPA 1 as control class. In experiment class, cooperative learning model Student Team Achievement Division (STAD) assisted by student worksheet (LKS) given, whereas
\end{abstract}


conventional learning model was applied in control class. The result of statistic test at significant level $(5 \%)$ showed that tcount $(3,76)>$ ttable $(1,67)$. The average score of experiment class is 70,83 with classical mastery $53,12 \%$ which is higher than the average score of control class is 68,01 with classical mastery $38,70 \%$. Based on these results it can be concluded that the application of cooperative leraning model Student Team Achievement Division (STAD) assisted by student worksheet (LKS)will give better effect on the students' chemistry learning outcomes on hidrocarbon at class XIIPA SMAN 7 Mataram.

Keywords : cooperative leraning model Student Team Achievement Division (STAD),student worksheet (LKS) and learning outcomes

\section{PENDAHULUAN}

Ilmu kimia merupakan salah satu mata pelajaran yang dilaksanakan dalam pembelajan di SMA. Ilmu kimia tidak terlepas dari kehidupan seharihari sehingga bermanfaat untuk dipelajari. Pentingnya ilmu kimia dalam proses pembelajaran siswa diharapkan dapat mencapai nilai di atas Kriteria Ketuntasan Minimal (KKM) sebagai bukti bahwa siswa telah mencapai tujuan pembelajaran kimia (Sulistyanti, dkk., 2019). Menurut Suyanti (2010) banyaknya konsep kimia yang bersifat abstrak yang harus diserap siswa dalam waktu relatif terbatas menjadikan ilmu kima merupakan salah satu mata pelajaran sulit bagi siswa sehingga banyak siswa kimia siswa berada di bawah KKM. Begitu pula yang terjadi di SMAN 7 Mataram, hasil belajar kimia siswa masih tergolong rendah karena nilai siswa yang cenderung di bawah KKM yaitu sebesar 75 . Indikasi rendahnya hasil belajar kimia siswa juga dilihat dari ketuntasan klasikal untuk semua kelas X IPA masih di bawah 40\%.

Permasalahan tersebut terjadi diduga karena dalam proses pembelajaran, guru langsung membahas hal-hal yang bersifat teoritis, sehingga siswa kesulitan untuk membayangkannya.Siswa cenderung hanya menghafal pengetahuan tanpa memahami informasi tersebut sehingga siswa tidak dapat membangun konsepnyasendiri. Walaupun penjelasan yang dilakukan oleh guru sangat lengkap mungkin hanya beberapa kata yang diingat siswa. Keadaan dan situasi inilah yang di duga membuat hasil belajar siswa kurang maksimal pada mata pelajaran kimia.
Sebagaimana juga dengan materi senyawa hidrokarbon (Sholihah, dkk., 2019).

Senyawa hidrokarbon merupakan sebuah senyawa yang tersusun atas unsur atom karbon (C) dan juga atom hidrogen $(\mathrm{H})$. Seluruh hidrokarbon mempunyai sebuah rantai karbon dan atom-atom hidrogen yang saling berikatan pada rantai tersebut. Hidrokarbon merupakan dasar materi kimia yang erat kaitannya dengan kehidupan sehari-hari, yang berguna untuk mempelajari konsep-konsep kimia lebih lanjut. Materi hidrokarbon menjadi salah satu materi kimia yang menjadi konsep prasyarat untuk konsep lain. Jika konsep hirokarbon tidak dikuasai dengan benar pada kelas XI maka pada kelas XII siswa akan kesulitan mempelajari konsepsenyawa karbon dan turunannya. Materi hidrokarbon memiliki karakteristik materi yang umumnya tidak disukai dan dirasa sulit oleh siswa. Karakteristik materi hidrokarbon adalah sebagai berikut: 1) Materi hidrokarbon berisi fakta-fakta istilah yang jumlahnya banyak dan bervariasi yang harus dihafalkan; 2) Istilahistilah dalam materi hidrokarbon umumnya berupa nama-nama senyawa, sangat asing bagi siswa karena tidak ditemukan dalam kehidupan sehari-hari;3)Materi hidrokarbon merupakan materi yang padat, sehingga membutuhkan waktu yang lebih panjang dalam penyampaian materi di dalam kelas sehinga memicu rasa bosan bagi peserta didik (Hidayah dkk, 2016).

Hasil penelitian Siswaningsih dkk (2014) menunjukkan miskonsepsi yang dialami siswa lebih besar dari 75,0\% pada konsep kekhasan atom karbon dan struktur alkana, alkena dan alkuna. Penelitian Rendhana (2011) menunjukkan miskonsepsi peserta didik terdapat pada konsep isomer, sifat fisika dan sifat kimia. Untuk itu, dalam mempelajari materi hidrokarbon diperlukan model pembelajaran yang baik dan tepat, agar siswa menjadi lebih 
Chemistry Education Practice,2 (2), 2019 - 46

Asman Ardiyansyah, Eka Junaidi, Saprizal Hadisaputra

termotivasi. Menurut Nashar (2004) menyatakan bahwa motivasi belajar yang dimiliki siswasiswa dalam setiap pembelajaran sangat berperan untuk meningkatkan hasil belajar siswa dalam mata pelajaran tertentu. Selain itu guru juga harus dapat menciptakan kondisi pembelajaran yang dapat membuat siswa aktif dalam membangun sendiri pengetahuannya.

Mengacu pada keadaan diatas dapat dikatakan bahwa proses pembelajaran yang dilakukan masih belum berjalan dengan maksimal sehingga dibutuhkan sebuah strategi pembelajaran baru yang dapat membuat siswa aktif dan terlibat langsung dalam proses pembelajaran sehingga siswa dapat membangun pemahamannya sendiri. Sebuah strategi belajar yang dapat mendorong siswa mengkontruksikan konsep-konsep pembelajarannya sendiri. Untuk meningkatkan hasil belajar, proses pembelajaran dapat dilakukan dalam bentuk kegiatan yang mengarahkan siswa untuk bekerja dan mengalami semua proses belajar secara berkelompok, selalu mengaitkan setiap materi dan memberikan penguatan.

Salah satu model yang dianggap tepat adalah model pembelajaran kooperatif tipe Student Team Achievement Division (STAD). Menurut Rusman (2012), model STAD (Student Team Achievement Division) merupakan variasi pembelajaran kooperatif yang paling banyak diteliti. Menurut Isjoni (2010), model pembelajaran kooperatif tipe STAD dikembangkan oleh Slavin dan merupakan salah satu tipe kooperatif yang menekankan pada adanya aktifitas dan interaksi antar anggota kelompok yang terdiri dari 4-6 siswa dengan tingkat kemampuan dan jenis kelamin yang berbeda untuk saling memotivasi dan membantu dalam menguasai materi pelajaran guna mencapai prestasi yang maksimal.

Penerapan model pembelajaran kooperatif tipe Student Team Achievement Division (STAD) diharapkan siswa dapat memahami materi hidrokarbon karena model pembelajaran Student Team Achievement Division (STAD) dapat membuat siswa untuk saling memotivasi dan saling membantu dalam menguasai materi pelajaran guna yang maksimal. Penggunaan model pembelajaran kooperatif tipe Student Team Achievement Division (STAD) ini diharapkan dapat meningkatkan hasil belajar siswa pada materi senyawa hidrokarbon.

Berdasarkan uraian latar belakang diatas, maka peneliti tertarik untuk melakukan penelitian dengan judul "Pengaruh Penerapan
Model Pembelajaran Kooperatif Tipe Student Team Achievement Division (STAD) Berbantuan Lembar Kerja Siswa (LKS) Terhadap Hasil Belajar Kimia Pada Materi Hidrokarbon Siswa Kelas XI IPA SMAN 7 Mataram”.

\section{METODOLOGI PENELITIAN}

Penelitian ini dilakukan di SMAN 7 Mataram pada bulan Maret 2019 sampai bulan Juli 2019. Penelitian ini termasuk kedalam jenis eksperimen semu (Quasi Experimental Design) yang terdiri dari kelas eksperimen dan kelas kontrol.Penelitian eksperimen semu digunakan karena pada penelitian ini sampel tidak dapat dikontrol sepenuhnya dari variabel-variabel luar yang mempengaruhi hasil belajar.

Desain penelitian yang digunakan dalam penelitian ini yaitu non equivalent control group design. Sampel dalam penelitian ini yakni siswa kelas XI IPA 3 (32 siswa) sebagai kelas eksperimen dan XI IPA 1 (31 siswa) sebagai kelas kontrol. Pengambilan sampel dilakukan dengan teknik purposive sampling atau teknik penentuan sampel dengan pertimbangan tertentu (Sugiyono, 2014). Cara demikian dilakukan jika anggota populasi telah dianggap homogen.

Penelitian ini dilakukan dengan pola pembelajaran pada kelas kontrol menggunakan model pembelajaran konvensional yaitu ceramah dan tanya jawab, sedangkan pada kelas eksperimen menggunakan model pembelajaran Model Pembelajaran kooperatif tipe Student Team Achievement Division (STAD) berbantuan lembar kerja siswa (LKS) Penerapan model dilakukan sebanyak 4 pertemuan dengan alokasi waktu 2 jam pelajaran (2x 45 menit). Pada pertemuan ke-1 dilakukan pretest dan pertemuan ke-6 dilakukan posttest dengan instrumen berupa soal esay.

Analisis data menggunakan Indeks Gregory untuk mengetahui validitas isi soal posttest, rumus product momen untuk mengetahui validitas butir soal dan rumus Alpha Crombach untuk mengetahui reliabilitas instrumen serta statistik uji-t untuk menguji hipotesis penelitian. Pengujian normalitas dilakukan dengan rumus chi-kuadrat dan uji homogenitas menggunakan rumus uji-F.

\section{HASIL DAN PEMBAHASAN}

Penelitian yang dilakukan ini difokuskan untuk mengetahui adanya perbedaan 
hasil belajar dalam ranah kognitif dari pengaruh penerapan model pembelajaran Kooperatif Tipe Student Team Achievement Division (STAD) Berbantuan Lembar Kerja Siswa (LKS) pada materi hidrokarbon.

Data hasil belajar siswa yang diperoleh berupa data hasil belajar dalam ranah kognitif pada materi hidrokarbon. Pretest danPost-test dilakukan pada kelas XI IPA 3 (kelas eksperimen) dan kelas XI IPA 1 (kelas kontrol) yang masing-masing berjumlah 32 dan 31 orang siswa. Rangkuman data dan grafik hasil belajar siswa disajikan pada gambar 5.3.

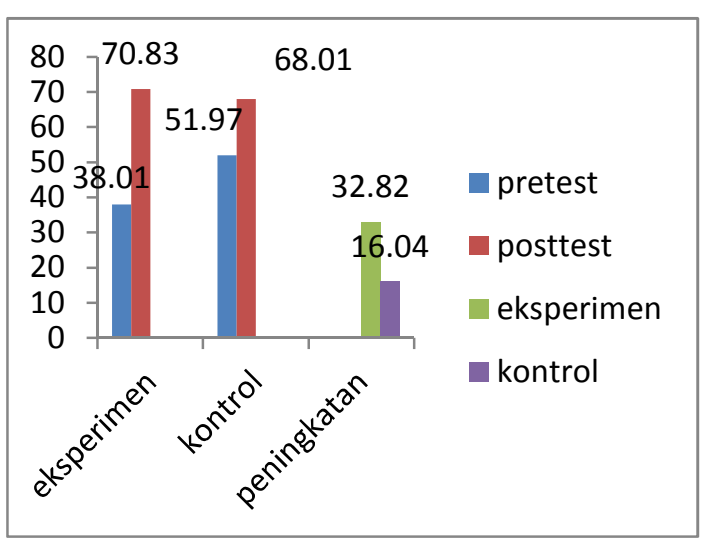

Gambar 1. Grafik Hasil Belajar

Berdasarkan grafik di atas, terlihat perbedaan yang cukup jauh dari nilai hasil belajar siswa pada kelas ekperimen dan kelas kontrol. Jika dilihat dari segi nilai rata-rata dan peningkatan maka hasil pretest pada kelas eksperimen adalah 38,01 dan hasil posttest dengan rata-rata 70,83 . Artinnya pada kelas eksperimen terdapat peningkatan sebesar 32,82. Pada kelas kontrol nilai rata-rata pretest sebesar 51,97 dan nilai rata-rata posttest sebesar 68,01 . Artinya pada kelas kontrol terdapat peningkatan sebesar 16,04. Berdasarkan peningkatan ratarata yang diperoleh maka dapat diketahui bahwa hasil belajar kelas eksperimen lebih tinggi dari pada kelas kontrol. Hal ini disebabkan oleh beberapa faktor yang menguatkan proses pembelajaran kooperatif tipe Student Team Achievement Division (STAD) berbantuan lembar kerja siswa (LKS) dalam penelitian ini. Adapun faktor tersebut adalah mengembangkan cara belajar siswa dengan menemukan sendiri dan saling memotivasi antar siswa sehingga hasil yang diperoleh tidak mudah dilupakan. Selain itu dengan adanya penggunaan media lembar kerja siswa (LKS) dapat meningkatkan minat dan motivasi belajar siswa, karena dalam LKS berisikan materi yang singkat, padat dan jelas sehingga memudahkan siswa untuk memahami materi pelajaran. Hal ini menunjukkan bahwa perlakuan yang diberikan pada kelas eksperimen berpengaruh lebih baik terhadap hasil belajar siswa.

Hal ini diperkuat dengan data yang di peroleh dari hasil uji N-Gain. Perbandingan ratarata hasil hitung skor gain pada kelas eksperimen dan kelas kontrol dapat dilihat pada gambar 5.4

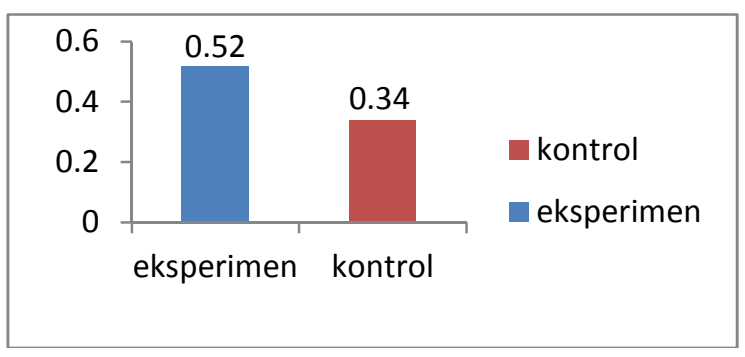

\section{Gambar 2. Perbandingan nilai N-Gain}

Hasil perhitungan skor gain pada kelas kontrol diperoleh nilai rata-rata pretest sebesar 51.97dan nilai rata-rata posttestsebesar68,01. Dari data tersebut terdapat 20 siswa berada pada kategori sedang dan 11 siswa berada pada kategori rendah. Sehingga diperoleh gain skor sebesar 0,34, artinya kelas kontrol mengalami peningkatan hasil belajar dengan kategori sedang karena $0,3<\mathrm{g} \leq 0,7$. Pada kelas eksperimen diperoleh nilai rata-rata pretest sebesar 38,01 dan nilai rata-rata posttestsebesar 70,83 . Hasil perhitungan skor gain pada kelas eksperimen terdapat 6 siswa pada kategori tinggi, 17 siswa pada kategori sedang dan 9 siswa pada kategori rendah. Sehingga diperoleh gain skor sebesar 0.52 , artinya kelas eksperimen mengalami peningkatan hasil belajar dengan kategori sedang karena $0,3<\mathrm{g} \leq 0,7$.

Pencapaian peningkatan hasil belajar pada kelas eksperimen dan kontrol cukup bagus, tetapi pada saat proses pembelajaran beberapa siswa kurang memperhatikan materi yang telah disampaikan oleh guru dan dalam melakukan proses diskusi sebagian siswa hanya melihat tanpa terlibat langsung dalam proses diskusi tersebut. Selain itu juga dalam melakukan diskusi sebagian hanya mengerjakan soal yang diberikan tanpa memahami makna dari soal tersebut yang sebenarnya berhubungan dengan materi yang dipelajari dan soal yang dikerjakan saat posttest, sehingga mengakibatkan pencapaian peningkatan keberhasilan kognitif siswa kurang maksimal. Apabila dibandingkan nilai $\mathrm{N}$-Gain kelas kontrol dan kelas eksperimen 
maka dapat disimpulkan bahwa model pembelajaran kooperatif tipe Student Team Achievement Division (STAD) berbantuan lembar kerja siswa (LKS) lebih efektif untuk meningkatkan hasil belajar siswa dibandingkan dengan model pembelajaran konvensional karena memiliki gain skor yang lebih tinggi.

Data hasil belajar tersebut selanjutnya dianalisis menggunakan uji-t. Hasil analisis uji-t menunjukkan bahwa nilai thitung sebesar 3,76 sementara untuk nilai ttabel pada taraf signifikan $5 \%$ dengan dk 61 diperoleh sebesar 1,67, dari nilai tersebut diketahui bahwa thitung $>$ ttabel yang menunjukkan bahwa Ha diterima dan Ho ditolak, sehingga dapat disimpulkan bahwa penerapan model pembelajaran kooperatif tipe Student Team Achievement Division (STAD) berbantuan lembar kerja siswa (LKS) memberikan pengaruh yang lebih baik terhadap hasil belajar pada materi hidrokarbon siswa kelas XI IPA SMAN 7 Mataram. Hasil penelitian ini sejalan dengan penelitian Fauziah dkk (2013). Hasil penelitian tersebut memiliki hasil thitung $(4,60)>$ ttabel $(1,669)$, sehingga penerapan model pembelajaran Student Team Achievement Division (STAD) memberikan pengaruh yang lebih baik terhadap hasil belajar siswa.

\section{KESIMPULAN}

Berdasarkan hasil penelitian dan pembahasan, dapat disimpulkan bahwa penerapan model pembelajaran kooperatif tipe Student Team Achievement Division (STAD) berbantuan lembar kerja siswa (LKS) memberikan pengaruh yang lebih baik terhadap hasil belajar kimia pada materi hidrokarbon siswa kelas XI IPA SMAN 7 Mataram. Di tandai dengan peningkatan hasil belajar adalah sebesar 32,82 .

\section{SARAN}

Berdasarkan penelitian yang telah dilakukan, peneliti mengajukan saran untuk keberlanjutan penelitian ini yaitu:

1. Diharapkan untuk peneliti selanjutnya dapat mengukur tidak hanya hasil belajar dalam ranah kognitif saja, tetapi dapat menambahkan nnya menjadi hasil belajar yang mencangkup dalam ranah afektif dan psikomotorik.

2. Diharapkan ketika melakukan penelitian dengan menggunakan pendekatan model pembelajaran kooperatif tipe Student Team Achievement Division (STAD) dapat diterapkan dalam materi yang berbeda.

3. Diharapkan untuk peneliti selanjutnya dapat mengatur waktu dengan baik, karena model ini memerlukan waktu yang banyak.

\section{DAFTAR PUSTAKA}

Fauziah, N., Masykuri, M., Agung, N. 2013. Studi Komparasi Metode Pembelajaran Student Team Achievement Division (STAD) Menggunakan Peta Pikiran dan Peta Konsep Terhadap Prestasi Belajar Siswa Pada materi Pokok Sistem Periodik Unsur Siswa Kelas X Semester Ganjil SMAN Kebakkramat Tahun Pelajaran 2012/2013. Jurnal Pendidikan Kimia. 2(2): 132-139.

Hidayah, N., Husna, A.M., Rody, P. S. 2016. Deskripsi Pemahaman Konsep Siswa Pada Materi Hidrokarbon Kelas XI IPA SMAN 9 Pontianak. Jurnal Pendidikan dan Pembelajaran. 5(9).

Isjoni. 2010. Pembelajaran Kooperatif Meningkatkan Kecerdasan antar Peserta Didik.Yogyakarta: Pustaka Pelajar.

Nashar, H. 2004. Peranan MotivasiKemampuan Awal dalam Kegitan Pembelajaran. Jakarta: Delia Press.

Rendhana. W. 2011. Miskonsepsi Siswa Pada Topik Hidrokarbon. Jurnal Pendidikan. 1(1).

Rusman. 2012. Model-model Pembelajaran Mengembangkan Profesionalisme Guru. Jakarta: Raja Grafindo Persada.

Sholihah, A., Laksmiwati, D., \& Haris, M. (2019). Pengaruh Pembelajaran Berbasis Masalah terhadap Prestasi Belajar Kimia. Chemistry Education Practice, 2(1), 24-29.

Siswaningsih, W., Hernani, H., Triannisa, R. 2014. Propil Miskonsepsi Siswa SMA Pada Materi Hidrokarbon Menggunakan Tes Diagnostik Pilihan Ganda Dua tingkat. Jurnal Penelitian Pendidikan Kimia. 1(2). 
Chemistry Education Practice,2 (2), 2019 - 49

Asman Ardiyansyah, Eka Junaidi, Saprizal Hadisaputra

Sugiyono. 2014. Statistika untuk Penelitian.

Bandung: Alfabeta.

Sulistyanti, L., Siahaan, J., \& Junaidi, E. (2019). Pengaruh Model Pembelajaran

Two Stay Two Stray (TSTS)

Dipadukan dengan Metode

Demonstrasi Terhadap Hasil Belajar

Kimia. Chemistry Education Practice, 2(1), 17-23.

Suyanti, R.D. 2010. Strategi Pembelajaran

Kimia. Yogyakarta: Graha Ilmu. 